\title{
LIBERATION THEOLOGY ACCORDING TO ABDURRAHMAN WAHID AND GUSTAVO GUTIÉRREZ
}

\author{
Sangkot Sirait \\ Universitas Islam Negeri Sunan Kalijaga Yogyakarta \\ e-mail:sangkot_sirait@yahoo.co.id
}

\begin{abstract}
This paper tells the thoughts of two religious figures who are concerned with talking about religion and humanity. These two figures are Abdurrahman Wahid and Gustavo Gutiérrez. The question that will be answered here is how the concept of the liberation of the two figures and where the difference lies and their implications for real life. The issues discussed here are related to theology, more popularly called liberation theology. The method used in this research is to read and examine the work of each of the two figures, both works that are called primary or secondary. After that, the concepts are compared according to their respective contexts. From the results of research on their works, an understanding is obtained that the theology of liberation is inspired by the real conditions of society that are of concern, both in terms of poverty and opportunity. Therefore, according to the two figures, religion must be able to solve the problem, it means that religion practised not only as a doctrine but also humanity. Action work of people who profess religion is needed to solve community problems. There are differences in the approaches of the two figures, namely Gutiérrez is more focused directly involved, while Wahid besides being directly involved, but also with a cultural approach and changing the way people think. The difference between the two approaches has implications for the process of change, namely Gutiérrez is more revolutionary mechanistic, while Wahid is more cultural and evolutionary
\end{abstract}

Abstrak: Tulisan ini merupakan sebuah hasil pembacaan atas pemikiran dua tokoh agamawan yang konsern dalam membicarakan tentang agama dan kemanusiaan. Dua tokoh dimaksud adalah Abdurrahman Wahid dan Gustavo Gutiérrez. Isu-isu yang dibahas di sini adalah terkait dengan teologi, yang lebih populer disebut dengan teologi pembebasan. Pertanyaan yang akan dijawab disini adalah bagaimana konsep pembebasan dua tokoh tersebut dan dimana letak perbedaan serta implikasinya terhadap kehidupan nyata. Metode yang digunakan dalam penelitian ini adalah dengan cara membaca dan menelaah karya masing-masing kedua tokoh tersebut, baik karya yang disebut primer maupun sekunder. Setelah itu baru kemudian konsep-konsep tersebut dibandingkan sesuai dengan konteks masing-masing. Dari hasil penelitian atas karya-karya mereka diperoleh pemahaman bahwa teologi pembebasan tersebut terinspirasi dari kondisi riil masyarakat yang memprihatinkan, baik dari aspek kemiskinan dan peluang. Oleh sebab itu, menurut kedua tokoh tersebut agama harus mampu memecahkan problem tersebut, yakni dengan cara agama dipandang bukan hanya sebagai sebuah doktrin tetapi juga kemanusiaan. Keterlibatan langsung orang yang mengaku beragama diperlukan untuk mememecahkan problem masyarakat. Namun 
demikian, ada perbedaan pendekatan dari dua tokoh tersebut, yakni Gutiérrez lebih fokus kepada keterlibatan langsung dalam pemecahan masalah kehidupan, sementara Wahid disamping terlibat langsung, juga dengan pendekatan budaya dan merubah cara berpikir masyarakat. Perbedaan dua pendekatan tersebut berimplikasi kepada proses perubahan itu, yakni Gutiérrez lebih bersifat mekanistik revolusioner, sementara Wahid lebih bersifat kultural dan evolutif

Keywords: Gustavo Gutiérrez, theology, poverty, injustice, indigenization.

\section{A. Introduction}

Theology, at first, was an unpopular term in Islamic discipline. This term appears in the Christian world and has a distinctive meaning. Later the term theology entered the Islamic world by adding the word Islam afterwards. Nevertheless, the meaning contained therein is different. In the Islamic world, theology is a scientific discipline that discusses divinity, while in the Christian world theology is synonymous with religion. Apart from the difference in the meaning of the word, that theology in both Islam and Christianity has the same object of study which concerns the problem of God. Today this word has various meanings and can be interpreted according to the context, among the words that can be accompanied by the word theology is the word "liberation".

The term liberation theology originally appeared in the Western/Christian regions initiated by various Christian or Catholic theologians. Meanwhile, in Indonesia also born a Muslim thinker who is engaged in the same field, that's Abdurrahman Wahid. Gutiérrez's theology is a reaction against the traditional method of understanding God. Gutiérrez said that the church would not have an authentic theology of liberation until those who are oppressed can express themselves independently and creative in society as human beings of God. Historically, the starting point of liberation theology was the social context in Latin America so this theology also cannot be applied fully to the context of society and Christianity in Indonesia. Here, Wahid is very well known as an expert on Islam with liberal thoughts, especially when religion is associated with the ethics of humanity. This can be explored from his works and his direct actions when he became a leader of a large ulama in a large organization such as Nahdatu al'Ulam $\bar{a}$ and while serving as a state leader. It is therefore interesting that the concepts of these two theologians are compared in the context of theology as a scientific discipline that talks about God and humans. 


\section{B. Liberation theology: discourse and practice}

Liberation theology is an understanding of the role of religion in the social sphere. In other words, liberation theology is an attempt to contextualize religious teachings and values on the concrete problems around them. ${ }^{1}$ Liberation theology is a contextual theological effort, it attempts to do theology contextually ${ }^{2}$ and makes the activities of churches committed to social life. Liberation theology was born in response to the economic and political situation that was judged to be miserable for the people. These problems are seen in oppression, racism, poverty, colonialism, ideological biases and so on. Among Jesuits, both in Asia including Indonesia, Brazil, Latin America and South Africa, this theology developed rapidly as a result of contextual hermeneutics of the Bible to answer the problems facing humanity. ${ }^{3}$ Liberation theology is a shared reflection of a community on a social problem. Because of that, people are involved in religious contemplations. They asked what kind of religious responsibilities and what religion should do in the context of structural poverty. Liberation Theology is an attempt to try to interpret the Scriptures from the perspective of the suffering of the poor. ${ }^{4}$

Liberation theology emerged in the 20th century as many of the world's problems stem from injustice, even though humans should be the same before God. The world must be free from the actions of humans who destroy each other, even the rich and officials should defend and pay attention to the needs of the people who are weak and poor. At first, this activity was focused on the problem of globalization, then it leads to the social sins inherent in a country's government system. Liberation theology offers a social system that promotes justice as citizens and citizens of the world in religious terms. Meanwhile, the theology of liberation

\footnotetext{
1 Paul E. Sigmund, Liberation Theology and The Crossroad (New York: Oxford University Press, 1990), 2.

2 Y. W. Wartaya Winangun, Tanah Sumber Nilai Hidup (Yogyakarta: Kanisius, 2004), 4.

3 Wahono Nitiprawiro \& Moh. Sholeh Isre, Teologi Pembebasan: Sejarah, Metode, Praksis, Dan Isinya (Yogyakarta: LKiS, 2000), 20.

4 Mateus Mali, “Gutierréz Dan Teologi Pembebasan," Orientasi Baru 25, no. 1 (2016): 28.
}

JURNAL THEOLOGIA — Volume 31, Nomor 1, Juni 2020 
born in Latin America focused on the resistance movement which was mostly carried out by religious figures against hegemony and authoritarian rule. 5

Liberation theology thought began with the Hermeneutics of the Bible. After interpreting the messages in the Bible based on Jesus' actions defending and helping the weak, sick, and oppressed, the role of religion should also be like that. In Christianity, this is the responsibility of the church as a religious institution that has influence, both to the congregation, the community in which it lives, and to its government. The values that emerge are usually seen from humanity and justice. Violations of these values in several countries have raised concerns among activists in liberation theology. For example, Christians with the teachings of Christology interpret that Christ is a person who is present in chaotic situations and brings deliverance to the small and oppressed people. From this, Christians follow Jesus' example and oppose injustice. They feel obligated to continue the work of God that they worship. ${ }^{6}$

In the Christian world, as written by Löwy's book, liberation theology is a synthesis between the religious movement and the left (Marxism) which has always been believed to be two perspectives that are impossible to unite. Few of the liberation theologians want the church to return to its function as the liberator of the oppressed. This refers to the history of the founding of the church itself, which has lasted two thousand years which is more accepted by the poor or the oppressed, and the church's concern for the poor is nothing new. They paid special attention to the Exodus section "as a paradigm of the struggle for the liberation of enslaved people". In its long activities, the church is still paying attention to the poor. But the approach used is merely generosity or tends to be paternalistic. This approach was opposed and changed by liberation theology. One of his doctrines states: "Poor people can no longer continue to be targets of generosity, but they must be individuals who are capable of their liberation. Assistance or fatherly assistance must be replaced with collective solidarity, poor people must be able to determine their destiny. Therefore, Löwy concludes that for the theologians of liberation "Marxism seems to be a systematic, concise and comprehensive explanation of the causes of poverty. Poverty as a humanitarian crisis occurs not only because the people who are less active in trying to prosper

${ }^{5}$ Isre, Teologi Pembebasan: Sejarah, Metode, Praksis, Dan Isinya, 25.

${ }^{6}$ A. Roy Eckardt, Menggali Ulang Yesus Sejarah (Jakarta: BPK Gunung Mulia, 1996), 10. 
themselves, but also due to oppressive structures. This means that the poverty that occurs in society is caused because they are oppressed by the economic system, political power and others that make their lives undeveloped. ${ }^{7}$ According to him, Marxism is the only radical conclusion that meets the requirements to eradicate poverty". Löwy does not dismiss the differences between Marxism and liberation theology. The most basic differences are the questions of materialist philosophy, atheist ideology, and the meaning of "religion as the opiate of the people. But in many cases, the difference is more the difference in interpretation of Marxism. ${ }^{8}$

For Gutiérrez, for example, Marxism not only provides a scientific analysis tool, but also a utopian will of social change. When entering political praxis, Lowy judged that liberation theologians were far more Marxist than those who claimed to be 'pure Marxists'. There is a view which recognizes that liberation theology is essentially inseparable from the concept of Marxism. ${ }^{9}$ Even Löwy questions the abilities of 'Marxist text-books' and 'crude materialists' who are far behind in praxis compared to liberation theologians who can read the objective conditions of Latin America. It was proven that liberation theologians brought extraordinary progress in social and political movements in Latin America, including in winning the Sandinista revolution in Nicaragua. It is also mentioned here that liberation theologians tend to condemn the views of Marxists who are considered "too scientific", like Althusser. They are more interested in "Western Marxism" which is often called "Neo-Marxism" like Ernst Bloch. But still what inspired them the most was a Latin American Marxist, Jose Carlos Mariategui. which warns that socialism in Latin America must not be a "pure imitation" or "copy" of existing socialism experiences, but rather is a "product of the struggle" itself. Isn't this similar to Bung Karno's views on Pancasila and Marhaenism? Betto replied: "For me, humans are not distinguished between those who believe and those who are

7 John A George Marthen Likumahwa, Titaley and Steve Gaspersz, "Keluar Dari Kemiskinan: Studi Pembangunan Dan Pemberdayaan Jemaat Di Dusun Siahari Kecamatan Seram Utara Timur," Arumbae: Jurnal Ilmiah Teologi Dan Studi Agama 2, no. 1 (2020): 93.

${ }^{8}$ Michael Löwy, Teologi Pembebasan, Kritik Marxisme\&Marxise Kritis (Yogyakarta: INSISTPress, 2013), 12.

${ }^{9}$ Fajar Gumelar and Hengki Wijaya, "Peran Gereja Masa Kini Menyikapi Teologi Pembebasan Gutiérrez," BIA': Jurnal Teologi Dan Pendidikan Kristen Kontekstual 2, no. 1 (2019): 19, https://doi.org/10.34307/b.v2i1.69. 
atheists, but between the oppressed and to be oppressed, between those who want to defend this unjust society and those who fight for justice. ${ }^{10}$

\section{Liberation Theology in Islam}

In Islam, freedom is a nature (fitrah) given by God. When one denies the other powers, it means he is already in the context of freedom. The conception of freedom in Islam is based on monotheism labelled as celestial religion of monotheism. Monotheism is a way of looking at the world, holistic and as harmonious system that transcends dichotomic boundaries, then is oriented towards the same divine purpose. As Faruqi said, monotheism is considered as a worldview and the principle of the social order should be able to answer worldly problems, like political, social and economic as well as divinity. ${ }^{11}$ Islam is no longer interpreted at the level of mere ritual formality, but it is oriented and driven by a spirit of humanity. Prophets like Noah, Musa, David, 'Isa and Muhammad were each inspired by religion and humanity. ${ }^{12}$ Hassan Hanafi, one of the contemporary experts who is known by his Islamic left, advocates that Islam be a transformative religion and has practical benefits for human civilization. According to him, Islam is not an institution of surrender that makes Muslims disempowered in the face of the power of the current development of society, but Islam is the basis of a populistic ideological movement that can free people from the chains of oppression. ${ }^{13}$

Reviving the oppressed is the highest form of human struggle in Islam. In Islam, liberation theology is an understanding of the role of religion in the social sphere. In other words, this concept is an attempt to contextualize religious teachings and values on the concrete problems around them and as a response to the economic and political situation that is troubling the people. Liberation theology in Islam is a term that only emerged in the late 20th century AD, but its existence essentially has existed since the birth of Islam. Because, from the

10 Dominggus Oktavianus, “Teologi Pembebasan: Titik Temu Agama Dan Marxisme?," http://www.berdikarionline.com, 2017.

11 Isma'il Raji Al-Faruqi, Tauhid, Its Implication for Thought and Life (USA: The International Institute of Islamic Thoughts, 1982), 85.

12 Isma'il Raji Al-Faruqi, 'Urubah and Religion: A Study of the Fundamental Ideas of Arabism and of Islam as Its Highest Moment of Consciousness (Amsterdam: Djambatan, 1962), 35.

13 Kazuo Shimogaki, Kiri Islam, Antara Modernisme Dan Post Modernisme, Transl. Imam Aziz and M. Jadul Maula (Yogyakarta: LKiS, 2012), 4. 
beginning, Islam came to free humanity from the bond of oppression and defend the oppressed. Glorifying women, fighting for a class for slaves to be free, fixing ignorant traditions such as killing baby girls, that is the task of Islam.

There are different contexts for the liberation theology in Islam and the Christian world. From Gutiérrez's perspective, liberation theology is motivated by the form of the class struggle of the proletariat from the bourgeois system, while in Islam, this concept came to improve the paradigm of Muslim thinking that always puts the demands of shari'ah, as a routine activity of religion, and not making the system of faith that can inspire Muslims in everyday life. In the level of amr ma'rüf nahi munkar, for example, so far the foundation has only been implemented in the structure of fiqh, like prayer, fasting, șadaqah, while the essence of the fiqh order is not implemented in the social sphere. In fact, according to Asghar Ali Engineer, liberation theology was born to take a role in defending oppressed groups, both oppression in religious and political matters. Referring to the above problems, then Islam should transform itself into social change. Islam does not only emphasize the formality of ritual worship but also must pay attention to social order such as justice and humanity. ${ }^{14}$ It should be that Islam becomes a system of belief (monotheism) that animates every Muslim to fight various oppressions. Islam frees humans from alienation by making liberation theology a method of its movement.

\section{Similarities and Differences the Two Figures for Liberation Theology}

\section{Abdurrahman Wahid's Liberation Theology}

Abdurahman Wahid, an Indonesian figure, once fought for the rights of the small people from the arrogance of the government in 1980. He is also known as a figure who fights for pluralism, which is an attitude of respecting human freedom in religion. This issue was conveyed through seminars, scientific meetings and even through changes in state law in Indonesia. ${ }^{15}$ Arif writes: "Abdurrahman Wahid (Gus Dur) criticized capitalism because he read Marxism. By following Gramsci, Wahid assessed that Marxism was trapped in 'rough economism' so that he did not see culture as a potential for change. From here

\footnotetext{
14 Asghar Ali Engineer, Islam Dan Teologi Pembebasan, Transl. Agung Prihantoro (Yogyakarta: Pustaka Pelajar, 1999), 32-33.

15 Isre, Teologi Pembebasan: Sejarah, Metode, Praksis, Dan Isinya, 25.
} 
Gramsci was also criticized because Wahid read the theology of liberation. Gramsci's mistakes, which did not see religion as a potential change, made Wahid interested in the Latin American Catholic theology movement which combines religion with Marxian critical analysis. ${ }^{16}$

Through this combination, he then criticized the theology of liberation, because according to him, this movement was trapped in ideology. It is this ideological quality that makes liberation theologians no longer free because they are trapped in the exclusivism of the movement. By assessing this condition, Wahid finally determined his model of movement in a structural religiously oriented, non-revolutionary movement. Wahid's thesis that Islam should encourage itself in the community development project was recorded clearly in some of his articles about the struggle of Islam with ideology and development. Among these writings, for example, "Development By Developing Ourselves", a paper at the 1979 ASEAN seminar in Penang, Malaysia; Jangan Paksakan Paradigma Luarterhadap Agama, Pengembangan Masyarakat Melalui Pendekatan Keagamaan and an introduction to Hasan Hanafi's work entitled Religion, Ideology and Development, as well as several other writings. The transformative function taken from the rich tradition and history of Islam became the main assumption of Wahid, and Islam should move independently without being burdened by the ties of any transformative ideology. ${ }^{17}$

The emergence of Islam's transformative function cannot be separated from the fact that this religion has from the beginning kept two mutually reinforcing dimensions. Islam as a religion that contains ideal principles, at the same time emphasizes action and liberation. This perfect combination of theory and action found its complete form within the framework of the vertical relationship between man and God, and the horizontal relationship between man and other creatures. Seeing such teachings, it can be imagined that Islam cannot be completely separated from the social empirical problem, in practice, Islam is always involved with interests outside of itself. Indeed, religion in this context seems to be 'value-free', thus opening up opportunities for change. The notion of 'interests' can be broadly elaborated, including the desires of state institutions in-

${ }^{16}$ Saiful Arif, Gus Dur Dan Ilmu Sosial Transformatif, Sebuah Biografi Intelektual, ed. Koekoesan (Jakarta, 2009), 20.

${ }^{17}$ Abdurrahman Wahid, Islam Kosmopolitan Nilai-Nilai Indonesia Dan Transformasi Kebudayaan (Jakarta: The Wahid Institute, 2007), 9. 
progress projects, or the will of religious leaders to change from unsatisfactory conditions imposed by the state. Muslims are asked to determine attitudes between supporting the status quo or opposing it. ${ }^{18}$ At this point, the discussion about the conception of liberation (based on religion) in Wahid's thought found its relevance.

He is not worried about criticizing some of the weaknesses of an act of liberation based on a weak culture, including Marx's wrong prediction, and calling religion "the opium of the people". For Marxism, the movement can be considered revolutionary, when it negates religion in itself. Not only criticism, but Wahid also said that the essential model of liberation is always rooted and directed to the highest appreciation of human social life. ${ }^{19}$ The focus of this idea is not only to realize the importance of a liberation movement from the hegemony of oppression but also to provide guarantees to the public so that they can free themselves. Therefore, Wahid finally chose the liberation action which he called structural change 'without Marx', or non-revolutionary structural transformation. Non-revolutionaries are important because, for Wahid, revolutionaries have a 'dark side', that is, positioning the cultural element not as a culture that stands alone and has the right to live but only as an ideological means for the achievement of the revolution. Thus, diversity was destroyed for the success of the revolution, which then gave birth to uniformity and new institutions that did not support it.

From this uniformity occurred what Wahid called the stolen revolution to maintain and consolidate the presence of only one party that won the revolution as happened in the 1979 Iranian Revolution or Joseph Stalin's 'theft' of the 1917 Bolshevik Revolution which created the dictatorship of communism. In Islam, ideological tendencies like this movement must be avoided, because according to Wahid, it creates exclusivism and extremism, even though it is based on the 'liberation paradigm'. For him, religion does save the power of liberation, but the world has its mechanism of change, so it's very risky when religion is relegated to the 'technical' level because religion can be transformed into an oppressive power in the name of the 'authority of heaven'. This is in line with the nature of liberation

18 Mahbib Khoiron, "Teologi Pembangunan Gus Dur Islam Dan Etika Pengembangan Masyarakat," Jurnal Pesantren Ciganjur, 2017.

19 Saiful Arif, Gus Dur Dan Ilmu Sosial Transformatif, Sebuah Biografi Intelektual, 254.

JURNAL THEOLOGIA — Volume 31, Nomor 1, Juni 2020 
which he outlines as "liberation without any other basis, except humans themselves. ${ }^{20}$

This is where the importance of positioning Islam as social ethics. The ethical liberation orientation held by Wahid refers to a political goal that does not presuppose a counter-political structure of the order to be changed. In this way, a movement will be saved from ideological character. This ethical emphasis makes Wahid's liberation strategy not socio-political but rather socio-cultural. This means that the indigenization of Islam is an inevitable process when religion meets local culture. ${ }^{21}$ This belief was once practised by Wahid when dealing with New Order hegemony, namely developing the transformative function of Islam as a critique of the practice of oppression, while doing something that is directly related to the real needs of the community. This is evident that Islamic domestication is not merely cultural. For Wahid, domestication of Islam is conditio sine qua non for the movement of the function of Islamic social ethics. Because Islam has reconciled tensions with culture through cultural indigenization, Islam is no longer trapped in a symbolic struggle, then the struggle of Islam is no longer merely symbolic.22 Islam which has grounded its culture can finally rise to the level of the main values (Weltanschauung) of Islam itself, which is centred on justice, equality and democracy.

These three values become the image of Islam because with its Islam protects the five basic human rights, namely, protection of the right to life, thought, belief, personal property rights, and the sanctity of the family. So, the value of justice, equality before the law, and democracy are structural conditions that must be realized to move the protection of these basic human rights. Something is interesting about Wahid's approach, namely his rejection of the supplementary approach that many do by activists who carry on behalf of religion (Islam).

According to him, there is a belief that on the one hand religion can free people from a certain structural pressure, but on the other hand, religion is often unable to do that. We must believe that religion does have the effect of liberation.

\footnotetext{
20 Khoiron, "Teologi Pembangunan Gus Dur Islam Dan Etika Pengembangan Masyarakat," 87.

21 Kamarudin Salleh, Khoiruddin Bin, and Muhammad Yusuf, "Gus Dur Dan Pemikiran Liberalisme," Ar-Raniry: International Journal of Islamic Studies 1, no. 2 (2014): 277.

22 Abdurrahman Wahid, Dialog Peradaban Untuk Toleransi Dan Perdamaian (Jakarta: Gramedia Pustaka Utama, 2010), 4.
} 
It's just that the process is slow and takes a long time. There are often problems, that is, we are often influenced by paradigms outside religion by demanding something in the name of religion itself. ${ }^{23}$ From his rejection of this supplementary approach, Wahid proposed fundamental religious involvement through a complementary approach. The complementary approach requires the involvement of religion (at least religious institutions) in setting development goals, methods and advice needed for that, and setting the orientation of development itself. Thus, religion was involved in development from the beginning. Together with other elements in development, religion plays a mutually supportive role in setting development goals and ways to implement them. ${ }^{24}$ It was very clear that Wahid was convinced that community development work should have given full thought and became part of religious principles and behaviour itself.

This is different from the supplementary approach, which controls religion to agree with development initiatives through doctrinal 'engineering' outside the understanding of the religious community itself. The complementary approach would instead restore religion to its essential ethos, namely, the attention of humanity and the realization of a just life. To obtain this ethos, it is necessary to explore the main values of the history of the Muslim community since the beginning and the treasury of Islamic tradition. Many indicators can be inventoried to show Wahid as a liberal theologian. In some of his writings, found lots of terminologies that leads to freedom such as liberating religion, religion of compassion, development theology, structural insight religion. ${ }^{25}$

The transformative value of Islam itself is considered important, because some Muslim thinkers take the ideology of liberation from outside of Islam, while on the other hand there arises the ignorant attitude of the clergy (at least religious institutions) to deal with social problems. In fact, in Wahid's view, the non-secular attitude of Islamic behaviour is important because it can provide orientation and development theory from the treasures of religious teachings. ${ }^{26}$ The spirit of a

${ }^{23}$ Abdurrahman Wahid, Prisma Pemikiran Gus Dur (Yogyakarta: LKiS, 2010), 167.

${ }^{24}$ Abdurrahman Wahid, Muslim Di Tengah Pergumulan, ed. Lappenas (Jakarta, 1981), 5.

${ }^{25}$ Khoiron, "Teologi Pembangunan Gus Dur Islam Dan Etika Pengembangan Masyarakat," 254.

${ }^{26}$ Abdurrahman Wahid, Islamku, Islam Anda, Islam Kita: Agama Masyarakat Negara Demokrasi (Jakarta: The Wahid Institute, 2006), 184. 
new understanding of Islam is thus a necessity. One way that can be taken, according to Wahid, is by stimulating and fundamentally changing the worldview and work ethic of Muslims through developing new beliefs in religious life. Theology or religion must be positioned in a new perspective, for example, highlighting the problem of poverty and injustice in a dynamic, non-fatalistic perspective. That is, Islam moves progressively from closed theological dogmatism to a universal struggle that touches the real problems of people's lives.

According to Wahid, the teachings of Islam are liberating religions. Historically, Islam has emerged as a criticism of the injustices found in the Arabian merchant community in the past, though not directly. This is the reason why Islam concentrates on formulating practical ways to overcome such injustice. During the New Order administration, Wahid was consistent in fighting for the fate of residents affected by the construction of the Kedung Ombo reservoir. Wahid suggested activists write a letter of protest to the World Bank to show responsibility for the project. Suharto was furious about the letter and told Wahid to apologize.27

Like Câmara, Wahid's struggle to fight for justice was also carried out with a nonviolent strategy and became a bridge between all interfaith groups. Relevant to Wahid, Câmara called for each religious community to unite and reopen the holy book and find universal teachings to fight the real enemy, that is injustice. ${ }^{28}$ Wahid had the opportunity to not only fight " from the underside", but also "from overside." When he was chairman of the Nahḍatu al-'Ulamā Grand Board (PBNU), Wahid struggled to develop and empower civil society. Although not too close, he did not leave the Suharto government at all. When he was president of Indonesia, the values he championed did not change at all and the results of the struggle were inherent in his policies. The values that underlie his spirit never change. Lots of new government policies tend to defend the oppressed. Here, he becomes a "liberation theologian" who moves "from overside.

According to Wahid, indigenization of Islam is an understanding which always considers local needs in formulating religious laws without changing the law itself. Indigenization of Islam is not an attempt to leave norms for the sake of culture, but so that norms accommodate cultural needs by sticking to the understanding of the shari'ah, Here, the revelation in the view of Wahid, must be

\footnotetext{
${ }^{27}$ Greg Barton, Biografi, Gus Dur, The Authorized Biography of Abdurrahman Wahid, Translated by Lie Hua (Yogyakarta: LKiS, 2002), 188-273.

28 Dom Hélder Câmara, Spiral of Violence (Sydney: Sheed and Ward Ltd, 1971), 37.
} 
understood by considering contextual factors, including legal awareness and a sense of justice. ${ }^{29}$

2. Abdurrahman Wahid and Religious Pluralism

For Wahid, pluralism is a broad perspective to find truth everywhere. He was a person who stood in the middle of a mass that was built in a very monolithic order, both at the level of ideology, politics, culture, and religion. In the framework of the New Order from 1965 to the 80s, the community wanted to be directed to a uniform order of life and mindset, both in the fields of ideology, education, and organizational rules. The spirit of pluralism can also be seen how he discussed peace education in the archipelago, both on formal and informal lines. This is initiated so that cultural values of ancestral heritage, such as mutual respect, could be appreciated in education. The approach used by Wahid is a socio-cultural approach, namely by building community life systems that are following the cultural insight of the archipelago. ${ }^{30}$ In the context of pesantren education, educational institutions must have the principle of freeing education from a single truth claim, democratic, respect each other, and respect diversity. ${ }^{31}$

Gus Dur's commitment to pluralism can be seen in part in his defence of minorities. During the New Order era in 1996, Abdurrahman surprised the public because he defended a pair of brides, named Budi Wijaya and Lanny Guito who were Confucians. The couple had difficulty when they wanted to register their marriage at the Surabaya Civil Registry Office. Civil Registry officials refused to register the marriage because Confucianism was not considered a legal religion in Indonesia. Finally, the couple was asked to choose one of the five religions recognized by the country at that time so that their marriage could be recorded and approved by the state. ${ }^{32}$

Wahid's ideas about tolerance and dialogue between religions or interfaith are inherent in his thinking about pluralism. If someone thinks positively about

\footnotetext{
${ }^{29}$ INCReS team, Beyond The Symbols: Jejak Antropologis Pemikiran Dan Gerakan Gus Dur (Bandung: Remaja Rosdakarya, 2000), 44.

${ }^{30}$ Halimatus Sa'diyah \& Sri Nurhayati, "Pendidikan Perdamaian Perspektif Gus Dur: Kajian Filosofis Pemikiran Pendidikan Gus Dur," Tadris: Jurnal Pendidikan Islam 14 (2019): 181.

31 Sri Handayani Diyan Dwi Nur I, Bambang Soepeno, "Gus Dur Ideas About Modernization Of Islamic Boarding School ADiyan," Jurnal Historica 2, no. 2 (2018): 230.

32 Taufani, “Pemikiran Pluralisme Gusdur," Jurnal Tabligh 19, no. 2 (2018): 214.
} 
pluralism, then automatically it contains a tolerant attitude towards diversity. ${ }^{33}$ Dialogue and tolerance for Catholic intellectuals and spirits are quite advanced and explicit, especially when referring to documents known as the Second Vatican Council document. This document contains the values of attitudes and new awards towards other religions. When he met with this kind of group from Christians, he did not feel strange with the mindset that was outside the Islamic horizon. In this case, he has a certain theological attitude that is not just being tolerant and dialogical but also being respectful of the different religions.

Two important things must be considered concerning dialogue in religious life. First, Wahid argues that differences in religions tend to be differences that are on the level of humanity. He said that the one who became the judge to say someone entered heaven and hell was God himself. Religious leaders, scholars, preachers, or anyone can not make judgments to people while in the world. Because he realizes that there are many hidden things in one's life while living in the world and that only God knows. Therefore, it is God who will determine whether a person is right or wrong in the hereafter. I think that thought is a kind of "radicalism in theology", which is now better known as "universal theology". Universal theology places the truths of religions only within the framework of the absoluteness of God. ${ }^{34}$ As for the others are relative, including faith that is believed by people throughout the world. I think this is the basis of theology which makes humanity not nervous with the differences that exist in religions or people of faith. Second, Wahid also stepped on more practical aspects. For him, religious praxis becomes something very essential in interreligious relations based on tolerance and concrete steps. Wahid built religious thought based on the teachings of Islam, which aims to elevate humans, realize the benefits and prosperity between them, and provide happiness in life. Religion does not exist to provide difficulties, intimidation, terror, and various damages on earth. ${ }^{35}$

As proof, he cooperates openly with anyone, whether in Christian, Hindu, Buddhist, or other Islamic groups. Although later he had a lot to do with secular organizations which rarely discussed religious doctrines or dogmas.

33 Abdurrahman Wahid, Pergulatan Negara, Agama, Dan Kebudayaan (Jakarta: Desantara, 2001), 111.

${ }^{34}$ Abdurrahman Wahid, Passing Over: Melintasi Batas Agama, ed. Komaruddin Hidayat dan Ahmad Gaus AF (Jakarta: Gramedia Pustaka Utama, 2001), 51-59.

35 Alif Pratama Susila, "Studi Analisis Terhadap Pemikiran Abdurrahman Wahid Tentang Agama," Jurnal Aqidah Dan Filsafat Islam 2, no. 1 (2017): 125. 


\section{Gustavo Gutiérrez: Humans are Oppressed}

In general, the concept of Gutiérrez's theology consists of three fields. First, theology is liberation from egoism and sin, the re-establishment of relations with God and with others. Second, theology includes political and social liberation, the elimination of policies that directly causes poverty and injustice. Third, liberation which includes the emancipation of the poor, and oppressed groups of all forms that prevent them from developing themselves. ${ }^{36}$

Gustavo Gutiérrez Merino, O.P is a Peruvian theologian and Dominican priest who is considered the founder of Liberation Theology. He served as Professor John Cardinal O'Hara in theology at the University of Notre Dame. He has been a professor at the Pontifical Catholic University in Peru and a visiting professor at many of the leading universities in North America and Europe. ${ }^{37} \mathrm{He}$ is a member of the Peruvian Language Academy, and in 1993 he was awarded the Legion of Honor by the French government for his tireless work. He is recognized as a liberal theologian from several founders of liberal theology in Latin America. He is a professor at Pontifical Catholic University in Peru and visiting lecturers at many North American and European universities. Much of his life was spent with poor people and work for their daily needs. ${ }^{38}$ For him, community ethics should be built based on mutual reflection which is carried out in real life. His theology centred on the alleviation of the poor who were treated unfairly by the system of class society which classifies humans into bourgeois categories (usually wealthy aristocrats) and proletarians (commoners who only have children but without possessions).

This is in response to the Karl Marx class society which according to him is due to the dominance of capitalism. Liberation theology referred to by Gutiérrez is alleviation in the political and social fields. Even though it starts with political understanding, this is not a depreciation of faith, but a reflection of faith that goes beyond social and political reflection. So, his theology centred on the historical Judaism of Jesus Christ. Gutiérrez states that Jesus Christ is "The poor" who is equated with the people who are oppressed today in the world. This is also based

36 Gustavo Gutiérrez, A Theology of Liberation: History, Politics, Salvation (Maryknoll: Orbis Book, 1973), 157.

37 Tony Lane, Runtut Pijar (Jakarta: BPK Gunung Mulia, 2007), 6.

38 Y. W. Wartaya Winangun, Tanah Sumber Nilai Hidup, 35. 
on the Gospel of Matthew 5:10. The deliverance of Jesus on the cross played two aspects, namely freeing humans from worldly oppression (physical and socialpolitical life) and oppression of faith (sin, death, mortality etc.) ${ }^{39}$

Gutiérrezalso theologizes using the biblical source, which is the story of Job who struggled with the miserable story that was considered by the Teodisees to be a crime. Gutierrez and Job view that evil and suffering do not originate from God, but rather a moral value that goes beyond human law. Through the story of Job who argued with his friends who said that Job's suffering was the result of sin, then this view automatically is no longer absolute, because suffering and evil are the fusion of God's love through unconditional love. ${ }^{40}$ Spiritual poverty for the writer has its meaning. This shows a first step in the transformation of faith. The author concludes that Gutiérrez wants to say that people who have spiritual poverty are people who are rich in faith, because by having it humans can practice faith in Jesus, by loving humans. Gutiérrez's theology did well in Latin America, this is because the majority of Latin American people are Catholic, and religion greatly influences their daily lives, most of them are poor people and they are poor followers of Jesus. Therefore, Gutiérrez wants to build a Christian liberation movement based on Jesus that teaches love in the form of solidarity, for the realization of the kingdom of God. Poverty is structural sin because it is a result of the injustice of the wealthy ruling elite. Injustice is a sin because it is contrary to God's love that requires solidarity.

There can hardly be any doubt that the formulation of the fundamental theological question has been a primary concern for Gutiérrez throughout his entire life: what does it mean to do theology? The focus of Gutiérrez is to reflect around the question of who God is and Gutiérrez translates theology as a way of speaking about God: "How are we to talk about a God who is revealed as love in a situation characterized by poverty and oppression?" 41 Poverty is called structural sin because it is the result of an unjust social structure that benefits certain elites. The unjust structure is sinful because it contradicts the principle of the Kingdom of God revealed by Jesus, it is necessary to develop a just and humane society. Gutiérrez's monumental work is A Theology of Liberation: History, Politics,

${ }^{39}$ Eckardt, Menggali Ulang Yesus Sejarah, 12.

40 Michael Taylor, Dilarang Melarat-Narasi Teologis Tentang Kemiskinan (Yogyakarta: Kanisius, 2007), 15.

${ }^{41}$ Gustavo Gutiérrez, A Theology of Liberation: History, Politics, Salvation, 19. 
Salvation (1971), explaining his understanding of Christian poverty requires an act of loving solidarity with the poor and in protesting liberation against poverty. According to Gutiérrez independence has three dimensions, firstly, one's involvement in the political and social fields, eliminating people from poverty and injustice. Second, free to involve themselves and emancipate against the poor, marginalized, oppressed and free them from all things that make them live limited to express their freedom and freedom in doing the best for themselves. Third, theology of liberation includes deliverance from selfishness and sin, the reestablishment of relations with God and with others.

In the Latin American context, Gutiérrez's liberation theology seems to arise from the conditions of the people in the region. The countries there are controlled by a group of wealthy elites, who maintain their position at the expense of the majority of the population. ${ }^{42}$ Since the world depression in the 1930s, the economies of countries in Latin America have relied heavily on exports of raw goods to Europe and Britain. Instead, they import factory commodities. After World War II, the price of raw materials fell on the world market. As a result, the economies of these countries are chaotic. They are also unable to import factory goods. To meet the needs of manufactured goods in the country, these countries launched modernization by spurring industrialization with the assistance of developed countries. They apply the system of capitalism as a model of modernization. Colonialism in Latin America in the 19th century began to change from political colonialism to economic colonialism. Western economic powers continue to exploit Latin America while working with the military-backed domestic power elite.

The peak of exploitation occurred in the 1950s when Latin America adopted a western economic model that was more capitalistic. The economic system of capitalism does not bring prosperity to the people as promised, even on the contrary, that poverty is everywhere. Only a few people enjoy wealth, while most people are in very poor condition. Capitalism strengthens the explorative socio-economic structure. More than that, this economic system strengthens Latin American dependence on western countries and complicates their economy. Internal market expansion and industrialization did not produce the

42 Marthinus Ngabalin, "Teologi Pembebasan Menurut Gustavo Gutierrez Dan Implikasinya Bagi Persoalan Kemiskinan," KENOSIS: Jurnal Kajian Teologi 3, no. 2 (2017): 130, https://doi.org/10.37196/kenosis.v3i2.10. 
expected results. There is even a big difference between developed countries (first world) and developing countries (third countries), wherein the 1960s to 1970 s the wealth of rich countries increased by $50 \%$.

Despite this situation, the Church does not seem to care about this. On the contrary, the Church as an institution of Christianity at that time became intimate with the rich who could protect their interests. Therefore, Latin American society must be freed, and Gutiérrez came up with the theology of liberation. Gutiérrez's release was based on socio-cultural criticism experienced by the surrounding community. Latin America is very thick with Catholicism, a religion that is a special guideline for society. The socio-cultural analysis examines the cultural dimensions of the lives of the poor and their relation to the general cultural dominance of society by the rich and powerful elite (dominant class). In Latin America, it concerns the popular religion. ${ }^{43}$

Religion is closely related to culture in general. The appreciation of one's faith is coloured by local cultural traditions, whereas daily lifestyle is influenced by religion. This phenomenon is known as a popular religion. Popular religion can be interpreted as the overall lifestyle of Latin American society in various forms, such as worldview, beliefs, language, dance, singing. All of this is their expression and assessment of all dimensions of life stemming from a combination of religious elements of Christianity and native culture. It is this popular religion that would become the main socio-cultural analysis category of Latin America. Popular religion is ambivalent towards poverty. It can be enslaving when it legitimizes the status quo of poverty. On the contrary, it can liberate when it inspires the struggle for freedom from poverty. In Latin America, religion has always been used to emphasize the dominance of the elite over the poor. Therefore, Gutierrez began the concept of the liberation of Latin American oppressed people, from those who dominated. Economic, political factors also contributed to the emergence of Gutiérrez's thoughts. The capitalist system can work if the political system also plays a role in it. The political situation in Latin America makes national stability tend to defend the interests of the bourgeoisie and suppress the aspirations of the poor. This political system is applied in Latin America so that class grouping can be maintained. The bourgeoisie is doing something on behalf of the state and

\footnotetext{
${ }^{43} \mathrm{Http}: / /$ filantropi29.blogspot.co.id/2016/09/kemiskinan-dan-teologipembebasan.html, “Kemiskinan Dan Teologi Pembebasan Gustavo Guiterrez," 2017.
} 
establishing the military as its law enforcement, and all forms of resistance to the state are non-nationalist and non-patriotic acts. The government uses the law as coercion to the people. The implementation of hegemony is embedded through values, ideology, lifestyle, and beliefs through educational facilities, the press, social organizations, and the Church. This is called a conflict based on the struggle of the poor, this conflict occurs between the poor and the rich. However, this conflict and struggle only question the unfair distribution of material, and his struggle is not to transform the poor. The transformative struggle of the poor must be fought by the poor themselves, and they must liberate themselves. Theology, according to Gutiérrez, a reflection of a concrete social process. ${ }^{44}$

The dominative socio-cultural system in Latin America makes religion very closely related to culture. The appreciation of faith is characterized by local culture, and people's daily lifestyles are influenced by religion. This is what is called popular religion. The lifestyle of Latin American people is an expression of their understanding and assessment of all dimensions of life stemming from a combination of religious Christianity and local traditions. ${ }^{45}$ This is the basis of Gutiérrez's analysis, that structural poverty is very closely related to popular religion. The main characteristic of Gutiérrez' theological reflection is the focus on the poor and their liberation. Which should be a priority, a change in social structure or change in human individuals that are expected to encourage changes in social structures that are not fair? Gutiérrez'once said: "Old theology wants to change people, to change the world; we want to change the world, so we can change people".46 There is a consistency in his way of dealing with this issue that could be perceived as arduous as if he always repeats himself and does not have anything new to say. But for Gutiérrez this consistency is necessary as the situation of the poor continues to be precarious in most contexts. One has, however, to be aware that there has been a development in Gutiérrez' theological reflection over time, but always with the poor in focus. ${ }^{47}$

${ }^{44}$ Olle Kristenson, Pastor In The Shadow Of Violence, Gustavo Gutiérrez as a Public Pastoral Theologian in Peru in the 1980s and 1990s (Sweden: Department of Theology \& Edita Västra Aros, 2009), 100.

${ }^{45}$ Martin Chen, Teologi Gustavo Gutiérrez (Yogyakarta: Kanisius, 2002), 63.

${ }^{46}$ Ignas Kleden, “Ilmu-Ilmu Sosial Dan Teologi Kontekstual," Jurnal Ledalero 17, no. 2 (2018): 196.

47 Kristenson, Pastor In The Shadow Of Violence, Gustavo Gutiérrez as a Public Pastoral Theologian in Peru in the 1980s and 1990s, 63. 
Latin American society is also an exploited Christian, and the poor are Christians who have faith. Therefore, their poverty experience cannot be separated from their religious comprehension of how they live that poverty. The church has an important role here because the church must choose between establishing the status quo of the rich or removing society from this structural poverty. At that time, the ruling group used the church to teach something that could support its strength. Therefore, Gutiérrez combines ideology and utopia. At that time the church was filled with the interests of the elite and the suffering of the poor. Gutiérrez always uses the term ideology in his concept because the rich use an ideology to establish their position, that's the capitalist ideology. While utopia is hope, used by the poor to achieve their hopes. Gutiérrez incorporated that value into the history of the struggle of the poor, not as nostalgia but as hope. When reading the scriptures, Gutierrez acted the same way. Scripture must be read and interpreted in the perspective of the poor and suffering. All this to form a new history, in which the poor participate in the liberation of existing classes. Class transformation must be done by the poor themselves because this change must be done from the bottom.

\section{E. Conclusion}

Gutiérrez's theology is a combination of orthodoxy and orthopraxis, where he formed a universal Church and had a humanist mission for humans and the church cares about what is happening in its environment. Theology is a critical reflection on praxis. Theological reflection serves to find a clear connection between struggle and Christian faith, Praxis is a fact that contains the struggle to be free from poverty. Poor people for Gutiérrez are victims of structural sin, they are victims of injustice, oppression, and despotism. They are not poor due to fate, Gutiérrez said that poor people are lazy, not creative and not competitive and not persistent, so they become poor. But the poor who are caused by structural sin, they are the subject of deliverance, Christian liberators must be able to struggle together with the poor, to realize the kingdom of God on earth. Gutiérrez also discussed the problem of spiritual poverty, which is a poor attitude before God, this attitude is needed so that humans can surrender to God in full. This spiritual poverty is needed because with it, humans love one another. He did not mention who is called the rich, but he said that the poor, is a social group that is exploited by other social groups. High social groups oppress low social groups. High groups 
in the Latin American social context are people who have everything, material, political rights, and they are elites who also control the Church as guardians of their status quo.

In the context of theology in general, no significant differences were found between Gutiérrez and Wahid. This means that both start from the views of their respective holy books, then the norms of the text are associated with the reality of religious community life. In both views, religion must be functional in life and not merely dogmas. The difference is seen in the strategies used by each, namely if Gutiérrez more directly eliminate poverty and at the same time facilitate them, while Wahid aside from such, he also uses cultural strategies to change people's lifestyles and thinking. Religion and strategy are two different things, and each has a contribution to solving the problem of humanity. Therefore, theology and social science complement each other and the contribution of theology to the understanding of society depends on the way it interprets its role. If religion does not address an unjust structure and is not a provision of God and does not see divisions between people, Wahid and Gutiérrez consider it not to be called faith. This is fundamental to our understanding of the interactions between the political, cultural, and theological reflection of the two figures.

\section{BIBLIOGRAPHY}

Al-Faruqi, Isma'il Raji. 'Urubah and Religion: A Study of the Fundamental Ideas of Arabism and Islam as Its Highest Moment of Consciousness. Amsterdam: Djambatan, 1962.

- - Tauhid, Its Implication for Thought and Life. USA: The International Institute of Islamic Thoughts, 1982.

Alif Pratama Susila. "Studi Analisis Terhadap Pemikiran Abdurrahman Wahid Tentang Agama." Jurnal Aqidah Dan Filsafat Islam 2, no. 1 (2017): 125.

Barton, Greg. Biografi, Gus Dur, The Authorized Biography of Abdurrahman Wahid, Translated by Lie Hua. Yogyakarta: LKiS, 2002.

Câmara, Dom Hélder. Spiral of Violence. Sydney: Sheed and Ward Ltd, 1971.

Chen, Martin. Teologi Gustavo Gutiérrez. Yogyakarta: Kanisius, 2002.

JURNAL THEOLOGIA — Volume 31, Nomor 1, Juni 2020 
Diyan Dwi Nur I, Bambang Soepeno, Sri Handayani. "Gus Dur Ideas About Modernization Of Islamic Boarding School ADiyan." Jurnal Historica 2, no. 2 (2018): 230.

Eckardt, A. Roy. Menggali Ulang Yesus Sejarah. Jakarta: BPK Gunung Mulia, 1996.

Engineer, Asghar Ali. Islam Dan Teologi Pembebasan, Transl. Agung Prihantoro. Yogyakarta: Pustaka Pelajar, 1999.

George Marthen Likumahwa, Titaley, John A, and Steve Gaspersz. "Keluar Dari Kemiskinan: Studi Pembangunan Dan Pemberdayaan Jemaat Di Dusun Siahari Kecamatan Seram Utara Timur." Arumbae: Jurnal Ilmiah Teologi Dan Studi Agama 2, no. 1 (2020): 93.

Gumelar, Fajar, and Hengki Wijaya. "Peran Gereja Masa Kini Menyikapi Teologi Pembebasan Gutiérrez." BIA': Jurnal Teologi Dan Pendidikan Kristen Kontekstual 2, no. 1 (2019): 14-26. https://doi.org/10.34307/b.v2i1.69.

Gustavo Gutiérrez. A Theology of Liberation: History, Politics, Salvation. Maryknoll: Orbis Book, 1973.

Halimatus Sa'diyah \& Sri Nurhayati. “Pendidikan Perdamaian Perspektif Gus Dur: Kajian Filosofis Pemikiran Pendidikan Gus Dur." Tadris: Jurnal Pendidikan Islam 14 (2019): 181.

Http://filantropi29.blogspot.co.id/2016/09/kemiskinan-dan-teologi-

pembebasan.html. "Kemiskinan Dan Teologi Pembebasan Gustavo Guiterrez," 2017.

Ignas Kleden. "Ilmu-Ilmu Sosial Dan Teologi Kontekstual." Jurnal Ledalero 17, no. 2 (2018): 196.

INCReS team. Beyond The Symbols: Jejak Antropologis Pemikiran Dan Gerakan Gus Dur. Bandung: Remaja Rosdakarya, 2000.

Isre, Wahono Nitiprawiro \& Moh. Sholeh. Teologi Pembebasan: Sejarah, Metode, Praksis, Dan Isinya. Yogyakarta: LKiS, 2000.

Kazuo Shimogaki. Kiri Islam, Antara Modernisme Dan Post Modernisme, Transl. Imam Aziz and M. Jadul Maula. Yogyakarta: LKiS, 2012.

Khoiron, Mahbib. "Teologi Pembangunan Gus Dur Islam Dan Etika Pengembangan Masyarakat." Jurnal Pesantren Ciganjur, 2017.

Kristenson, Olle. Pastor In The Shadow Of Violence, Gustavo Gutiérrez as a Public 
Pastoral Theologian in Peru in the 1980s and 1990s. Sweden: Department of Theology \& Edita Västra Aros, 2009.

Löwy, Michael. Teologi Pembebasan, Kritik Marxisme\&Marxise Kritis. Yogyakarta: INSISTPress, 2013.

Mali, Mateus. “Gutierréz Dan Teologi Pembebasan.” Orientasi Baru 25, no. 1 (2016): 19-36.

Ngabalin, Marthinus. "Teologi Pembebasan Menurut Gustavo Gutierrez Dan Implikasinya Bagi Persoalan Kemiskinan." KENOSIS: Jurnal Kajian Teologi 3, no. 2 (2017): 130. https://doi.org/10.37196/kenosis.v3i2.10.

Oktavianus, Dominggus. "Teologi Pembebasan: Titik Temu Agama Dan Marxisme?" http://www.berdikarionline.com, 2017.

Saiful Arif. Gus Dur Dan Ilmu Sosial Transformatif, Sebuah Biografi Intelektual. Edited by Koekoesan. Jakarta, 2009.

Salleh, Kamarudin, Khoiruddin Bin, and Muhammad Yusuf. "Gus Dur Dan Pemikiran Liberalisme." Ar-Raniry: International Journal of Islamic Studies 1, no. 2 (2014): 259-84.

Sigmund, Paul E. Liberation Theology and The Crossroad. New York: Oxford University Press, 1990.

Taufani. “Pemikiran Pluralisme Gusdur.” Jurnal Tabligh 19, no. 2 (2018): 214.

Taylor, Michael. Dilarang Melarat-Narasi Teologis Tentang Kemiskinan. Yogyakarta: Kanisius, 2007.

Tony Lane. Runtut Pijar. Jakarta: BPK Gunung Mulia, 2007.

Wahid, Abdurrahman. Dialog Peradaban Untuk Toleransi Dan Perdamaian. Jakarta: Gramedia Pustaka Utama, 2010.

-_- Islam Kosmopolitan Nilai-Nilai Indonesia Dan Transformasi Kebudayaan. Jakarta: The Wahid Institute, 2007.

-_- Islamku, Islam Anda, Islam Kita: Agama Masyarakat Negara Demokrasi. Jakarta: The Wahid Institute, 2006.

—_- Muslim Di Tengah Pergumulan. Edited by Lappenas. Jakarta, 1981.

_-_. Passing Over: Melintasi Batas Agama. Edited by Komaruddin Hidayat dan Ahmad Gaus AF. Jakarta: Gramedia Pustaka Utama, 2001. 
SANGKOT SIRAIT: Liaberation Theology According to Abdurrahman Wahid...

___. Pergulatan Negara, Agama, Dan Kebudayaan. Jakarta: Desantara, 2001.

. Prisma Pemikiran Gus Dur. Yogyakarta: LKiS, 2010.

Y. W. Wartaya Winangun. Tanah Sumber Nilai Hidup. Yogyakarta: Kanisius, 2004. 